\title{
General system of Neoptera with description of a new species of Embioptera
}

\section{Общая система Neoptera с описанием нового вида Embioptera}

\author{
Nikita J. Kluge \\ Н.Ю. КАюге
}

Department of Entomology, St. Petersburg State University, Universitetskaya nab., 7/9, St. Petersburg, 199034, Russia. E-mail: kluge@FK13889.spb.edu. Website: http://www.insecta.bio.pu.ru

Кафедра энтомологии, биолого-почвенный факультет, С.-Петербургский государственный университет, Университетская наб., 7 / 8, С.-Петербург 199034, Россия.

KEY WORDS: insects, systematics, phylogeny, Polyneoptera, Idioprothoraca, Notoptera, Embioptera, Rhipineoptera, Clothoda amazonica, new taxa.

КЛЮЧЕВЫЕ СЛОВА: насекомые, систематика, филогения, Polyneoptera, Idioprothoraca, Notoptera, Embioptera, Rhipineoptera, Clothoda amazonica, новые таксоны.

ABSTRACT. Embioptera and Notoptera comprise a holophyletic taxon Idioprothoraca taxon nov., which is characterized by a unique structure of prothoracic lateral walls, two-segmented cerci in the first larval instar and some other characters. Other insect, formerly placed to Polyneoptera Martynov, 1923, constitute a holophyletic taxon Rhipineoptera taxon nov., which is characterized by presence of anal fan on hind wings; all representatives of Rhipineoptera taxon nov., whose anal fan is reduced, retain its vestige. In contrast to them, Idioprothoraca taxon nov. initially have homonomous wings, and their ancestors never had anal fan. The taxon Neoptera is divided into Idioprothoraca taxon nov., Rhipineoptera taxon nov. and Eumetabola; the taxon Eumetabola is divided into Parametabola (= Paraneoptera s.1.) and Metabola (= Oligoneoptera). Various opinions about systematic position of Embioptera, Notoptera and Zoraptera are discussed. New species Clothoda amazonica sp.n. is described basing on male imagoes and nymphs from Peruvian Amazonia.

РЕЗЮМЕ. Embioptera и Notoptera образуют голофилетический таксон Idioprothoraca taxon nov., который характеризуется уникальным строением латеральных стенок переднегруди, двучлениковыми церками у личинки первого возраста и некоторыми другими признаками. Прочие насекомые, ранее помещавшиеся в Polyneoptera Martynov, 1923, образуют голофилетический таксон Rhipineoptera taxon nov., который характеризуется наличием анального веера на задних крыльях; у всех представителей Rhipineoptera taxon nov., у которых анальный веер редуцирован, сохраняются его вестигии. В отличие от них, y Idioprothoraca taxon nov. крылья исходно гомономные, и их предки никогда не имели анального веера. Таксон Neoptera делится на Idioprothoraca taxon nov., Rhipineoptera taxon nov. и Eumetabola; таксон Eumetabola делится на Parametabola (=
Paraneoptera s.1.) и Metabola (= Oligoneoptera). Обсуждаются различные мнения о систематическом положении Embioptera, Notoptera и Zoraptera. По имаго и личинкам из Перувианской Амазонии описан новый вид Clothoda amazonica sp.n.

\section{Introduction}

Martynov [1923, 1924, 1938] established the division Neoptera and divided it into three subdivisions Polyneoptera, Paraneoptera and Oligoneoptera. This classification became generally accepted; recently the three Martynov's subdivisions are widely recognized either as subdivisions, or cohorts [e.g., Rohdendorf, 1962], or supercohorts [e.g., Arillo \& Engel, 2006], or infraclasses [e.g., Kukalova-Peck, 1973], or rankless taxa. Among them, Oligoneoptera is a holophyletic taxon of insects with complete metamorphosis, whose oldest mane is Metabola (see below). The taxon Paraneoptera has a more monosemantic name Parametabola; I regard it to be holophyletic, while another opinion exists (see discussion on Zoraptera below). Hennig [1953] assumed that Metabola and Parametabola comprise a holophyletic taxon Eumetabola, that seems reliable (see below). The taxon Polyneoptera was originally characterized by a single apomorphic character presence of anal fan on hind wing. Some authors express doubt that this apomorphy testifies about holophyly of Polyneoptera, so they prefer to call this group "lower Neoptera" [e.g., Kristensen, 1995], but no other classification has been suggested. Among taxa included to Polyneoptera, there is an order Embioptera; Martynov mentioned this order as a member of Polyneoptera in all his publications about general insect systematics, including even the first one [Martynov, 1923], in which the list of taxa included was very incomplete. Unlike other members of Polyneoptera, Embioptera have nei- 
ther anal fan, nor its vestige. Thus, the taxon Polyneoptera has no any autapomorphies and even has no formal diagnosis. In this paper I give a modified classification, where insects formerly placed to an artificial taxon Polyneoptera, form two independent taxa - Idioprothoraca taxon nov. and Rhipineoptera taxon nov.

Names of high-rank insect taxa are given according to my previous paper [Kluge, 2010a], in agreement with the principles of circumscriptional nomenclature, which constituted a part of the dual nomenclature system.

Some figures used in this paper, were made from specimens of Embioptera belonging to an undescribed species. Here this species is described as Clothoda amazonica sp.n. Type material of this species is deposited in the Zoological Institute of Russian Academy of Sciences.

\section{Proposed classification and characteristics of taxa}

\section{Neoptera Martynov, 1923}

Circumscriptional synonymy:

= NeOpterygota Crampton, 1924

Typified name in basic format: Scarabaeus/fg (sine Libellula; incl. Embia, Forficula).

Autapomorphy. Wings have got ability to fold thanks to mobility of the $3^{\text {rd }}$ axillary sclerite; when the $3^{\text {rd }}$ axillary sclerite turns over, the wing turns by its apex backward, keeping its dorsal side dorsally.

Classification. The taxon Neoptera is divided into Idioprothoraca, Rhipineoptera and Eumetabola.

\subsection{IDIOPROTHORACA taxon nov.}

Typified name in basic format: Embia/fg (incl. Grylloblatta).

ETYMOLOGY. $ı$ Iós (special) + prothorax; due to autapomorphy in prothoracic structure [see character (1)].

CHARACTERISTICS. Autapomorphies of Idioprothoraca:

(1) Prothorax is modified as the following: pleurites are strongly diminished, and tergite is elongate in front of the pleurites; side walls of the prothorax in front of pleurites are formed by a pair of pseudopleurites - newly formed sclerites of a characteristic shape; dorsal part of the pleurite is dipped into the body, forming a sclerotized apodeme (Figs 1$2,4,7)$. Pseudopleurite forms a part of lateral wall of prothorax, but probably have originated from a lateral portion of tergite. In Embioptera, pseudopleurite is flat or somewhat convex and exposed laterally or laterally-dorsally; it can be separated from notum (i.e., dorsal part of tergite) by a membranous stripe or two membranous stripes with additional narrow sclerite between them (Fig. 4). Verhoeff [1904] indicated pseudopleurite of Embioptera as "Halspleuren", and Matsuda [1970] indicated it as "detached anterolateral part of the pronotum". In Notoptera, pseudopleurite is concave and exposed ventrally-laterally; its connection with notum forms a rigid, projected lateral ridge (Fig. 1). Walker [1938] indicated pseudopleurite of Notoptera as "underside of protergum"; Uchifune \& Machida [2005] call it "paranotum"; while Crampton [1915, 1917] regarded it to be a part of pleurite. Shape of pseudopleurite is the same in Embioptera and Notoptera: its dorsal margin is straight and adjacent to lateral margin of notum, and its anterior-dorsal angle coincides with anterior-lateral angle of notum; anteriorly and ventrally margin of pseudopleurite is smoothly rounded; posterior margin is incised and forms a right angle with ventral margin; diminished pleurite is located in the incision of posterior margin of pseudopleurite. Dorsally pleurite is continued to an apodeme, which penetrates under the incised margin of pseudopleurite. As pleurites of prothorax are diminished and located far from anterior margin of prothorax, cervical sclerites, being articulated with them, are elongated and stretch from pleurites to the head, being located ventrad of pseudopleurites. Each cervical sclerite is divided into two sclerites - anterior and posterior ones; the posterior cervical sclerite is transverse, short and wide; the anterior cervical sclerite is longitudinal, long, narrowing anteriorly. Thus, in Idioprothoraca neck is short, but neck sclerites are long. Structure of prothoracic lateral wall strongly differs from structure of meso- and metathoracic lateral walls [see (3)].

The presence of pseudopleurite is a unique feature of Idioprothoraca; apodeme, formed by dorsal portion of pleurite (cryptopleurite), besides Idioprothoraca, is found also in Saltatoria and Coleoptera.

(2) Cerci are 2-segmented at least in first-instar larva. In Embioptera cerci remain to be 2-segmented in all instars (Figs 6, 8). In Notoptera cerci are 2-semented in the first instar only [Fig. 3; Nagashima, 1991: Fig. 3; Uchifune \& Machida, 2005: Figs 4A-C, 11]; at each molt number of segments increases thanks to division of the most proximal segment, so that in imago cercus has 5-10 segments. In other insects cerci either consist of indeterminate number of segments beginning from the first instar (e.g., many Plecoptera, Pandictyoptera), or are one-segmented in all instars (e.g., Saltatoria, Spectra), or are multisegmented in larva and onesegmented in imago (e.g., some Plecoptera and some Dermatoptera); only in Tridactylidae cerci are 2-segmented.

\section{Probable apomorphies of Idioprothoraca:}

(3) Mesothorax and metathorax have similar structure different from structure of prothorax [see (1)]. Pleurites are much larger than that of prothorax, and strongly inclined, so that pleural suture stretches longitudinally nearly from anterior margin of the tergum to posterior margin of the segment. In accordance with this, in winged forms (male Embioptera only) wings are attached near anterior margin of the segment (Fig. 7). In larvae of these winged forms protopteron begins from anterior margin of tergum, and its epipleuron forms the whole lateral margin of the tergum (Fig. 5). In wingless forms (females of Embioptera and both sexes of Notoptera) the same epipleura of protoptera are present, being developed both in larvae and imagoes; they represent lamellate lateral margins of terga, which are bent down and cover dorsal areas of pleurites (Figs 1, 4) (the name "Notoptera" is connected with this feature).

Possibly, the common ancestor of Idioprothoraca had wings in males only, while its females were wingless (as recent Embioptera); in this case the form of wing vestiges, common for all Idioprothoraca, can be an autapomorphy of this taxon.

Structure of meso- and metathorax of winged and wingless Idioprothoraca is not unique: particularly, Dermatoptera have similar structure.

(4) Hidden mode of life and adaptations to move in narrow spaces: body is elongate and flexible; head relatively large, prognathous; ocelli are lost (the same in many other insects).

Plesiomorphy of Idioprothoraca, unique among Neoptera:

(5) Wings are initially homonomous: in Embioptera fore and hind wings can be indistinguishable in size, shape, venation and structure of axillary apparatus. In contrast to Rhipineoptera (see below), hind wing never has anal fan or its vestige. In some Embioptera fore and hind wings have got these or that differences in size, shape and/or venation, up to complete loss of hind wings. These differences are peculiar for selected taxa in Embioptera, but not to their common ancestor.

Among Idioprothoraca, wings are present only in male Embioptera, but absent in all female Embioptera and all 
Notoptera. In Notoptera meso- and metathorax have very similar structure and size (Fig. 1); this allows to assume that their winged ancestors could have homonomous wings.

The full homonomy of wings, initial for Idioprothoraca, is unique among Neoptera. In all other Neoptera, whose fore and hind wings are superficially similar (such as Isoptera, some Plecoptera, Neuropteroidea, Mecoptera, some Amphiesmenoptera), proximal portions of the fore and hind wings markedly differ in their venation and structure (Figs 910). Besides Embioptera, fully homonomous wings are found in some Odonata and Paleozoic Ephemeroptera (but not in recent Ephemeroptera).

DISCUSSION. Till now, Embioptera and Notoptera were attributed to Polyneoptera. The taxon Polyneoptera Martynov, 1923 represents a plesiomorphon, being characterized by plesiomorphies only - biting mouth apparatus, noncoupled wings and presence of cerci. Anal fan, which was declared by Martynov [1923, 1924, 1938] to be the main character of Polyneoptera, is completely absent in all Idioprothoraca [see character (5)].

CLASSIFICATION. The taxon Idioprothoraca is divided into two taxa - Embioptera and Notoptera.

\subsection{1. Емвioptera (Lameere, 1900) Shipley, 1904}

Circumscriptional synonymy:

$=$ ADENOPODA Verhoeff, 1904;

= OLIGONEURA Börner, 1904;

= EuPlatYPTERA Crampton, 1916;

= Netica Navas, 1918

Typified name in basic format: Embia/fg; typified names in use: Embiae, Embida, Embiida, Embidina, Embiidina, Embiodea, Embioidea, Embiaria, Embidaria, and others.

Circumscription of Embioptera. Embioptera include more than 300 species, distributed worldwide (Ross, web publication). In application to the recent fauna, circumscription and characteristics of Embioptera is well known and indisputable. Some authors attributed to Embioptera such extinct taxa, as Permian Protembia Tillyard, 1937, Tillyardembia Zalessky, 1938, Sheimia Martynova, 1958, and Jurassic Brachyphallophagus Rasnitsyn [in Rasnitsyn \& Krasilov, 2000]. Unlike true Embioptera, these insects had winged females with developed ovipositor and multisegmented cerci. As assumed synapomorphies of these insects with true Embioptera, only non-unique characters have been named, so placing of these insects to Embioptera is not grounded.

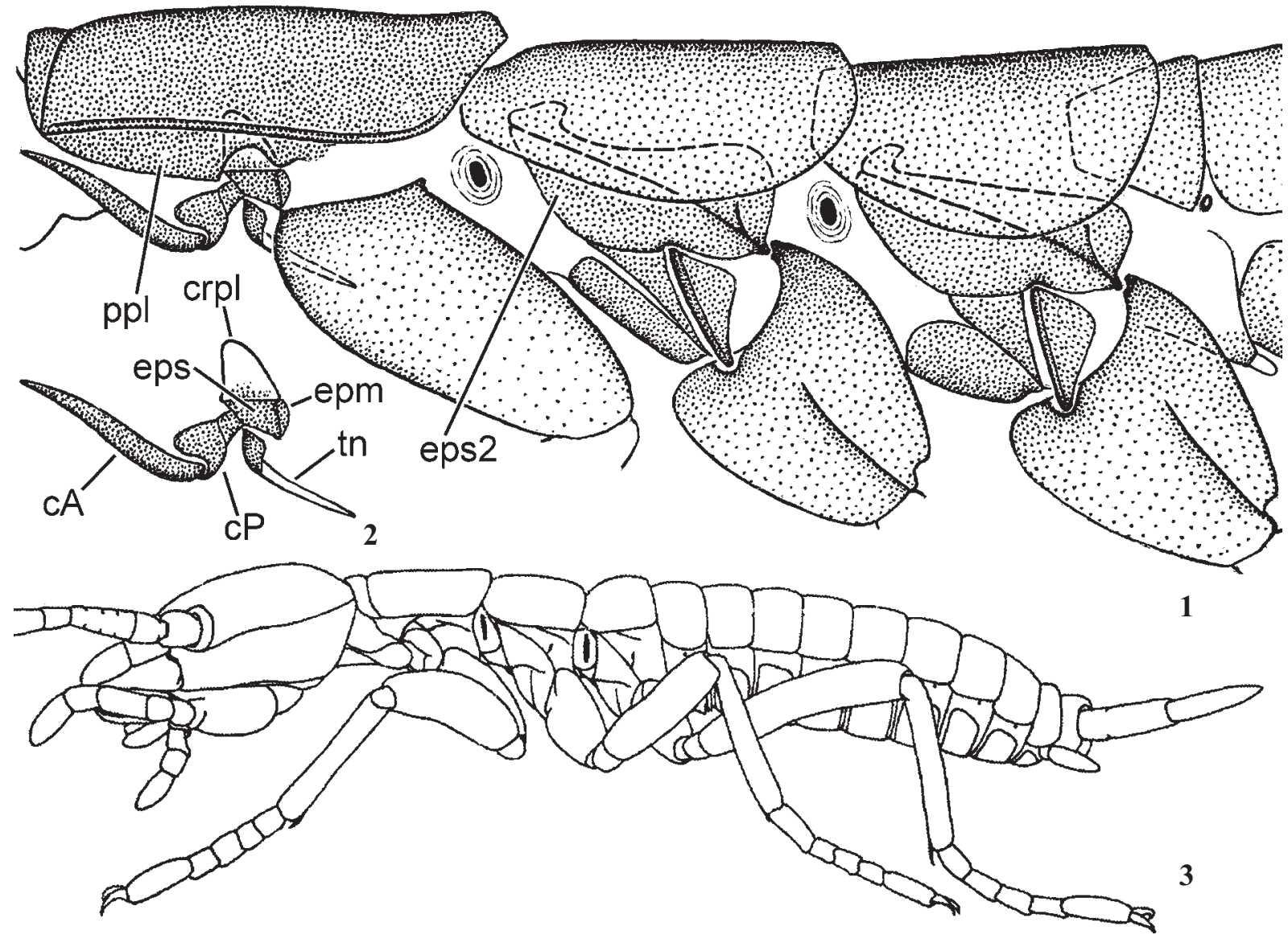

Figs 1-3. Notoptera: 1-2 - female imago of Grylloblattina djakonovi Bey-Bienko, 1951; 3 - first instar larva of Galloisiana yuasai Storozhenko, 1988 (after Uchifune \& Machida, 2005); 1 - thorax, lateral view; 2 - separately shown pleurite and cervical sclerites; cA — anterior part of cervical sclerite; $\mathrm{cP}$ — posterior part of cervical sclerite; crpl — cryptopleurite; eps — episternum of prothorax; eps 2 episternum of mesothorax; epm - epimeron of prothorax; ppl — pseudopleurite; tn - trochantin of prothorax.

Рис. 1-3. Notoptera: 1-2 — самка имаго Grylloblattina djakonovi Bey-Bienko, 1951; 3 — личинка первого возраста Galloisiana yuasai Storozhenko, 1988 (по Uchifune \& Machida, 2005); 1 - грудь, латерально; 2 - отдельно показанные плейриты и шейные склериты; сA - передняя часть шейного склерита; cP — задняя часть шейного склерита; crpl - криптоплейрит; ерs - эпистернум переднегруди; eps 2 — эпистернум среднегруди; epm-эпимерон переднегруди; ppl— псевдоплейрит; tn — трохантин переднегруди. 
Systematic position of Embioptera. In the past, some authors united Embioptera with Isoptera to a taxon ISOPTERA s.l. sensu Brullé, 1832: p.100, or AETIOPTERA Enderlein, 1909, which was characterized by homonomous wings. Actually, only Embioptera have really homonomous wings, while in Isoptera wing homonomy is secondary and always incomplete. Recently this idea is abandoned, because Isoptera are placed to a holophyletic taxon Pandictyoptera Crampton, 1917.

It is used to place Embioptera to a plesiomorphon Polyneoptera (see discussion on Idioprothoraca above).

Inside Polyneoptera, Embioptera were united either with Plecoptera to a taxon Plecopteroidea Martynov, 1934 [Martynov, 1938] (circumscriptional synonyms: Plecopteria Crampton, 1938 = PLECOPTERIDA Boudreaux, 1979), or with Plecoptera and Dermatoptera to a taxon PANPLECOPTERA Crampton, 1917 (circumscriptional synonym: HAPLONEURA Lameere, 1936). Both Plecopteroidea and Panplecoptera were characterized by non-unique characters only: prognathous head, elongated body, loss of styli, loss of ovipositor and 3 segmented tarsi. Among these characters, 3-segmented tarsi can not be initial for Embioptera and Dermatoptera, because Embioptera have signs of fore tarsomeres on hind legs (Figs 6-7), and Mesozoic Archidermaptera (which undoubtedly belong to Dermatoptera) had distinctly 5-segmented tarsi [Rasnitsyn \& Quicke, 2002].

Terry \& Whiting [2005] united Embioptera and Spectra to a taxon EUKINOLABIA Terry \& Whiting, 2005. Holophyly of this taxon was based on doubtful homologization of some muscles in labium and prothorax and on nucleotid sequences of some genes; however, no one gene character has been reported.

Rafael \& Engel [2006] united Embioptera and Zoraptera to a taxon Mystroptera Engel, 2006. The following characters are reported as synapomorphies of Embioptera + Zoraptera [Engel \& Grimaldi, 2000]: (1) loss of gonostyli; (2) cercus reduced to one or two segments; (3) enlarged hind femora with overdeveloped tibial depressor; (4) anal lobe of hind wing lost; (5) apterous morphs; (6) "dehiscent wings that are shed by a basal fracture"; (7) number of tarsomeres reduced to 3 or $2 ;(8)$ gregarious (maternal) behavior. Actually no one of these characters testifies about relation of these taxa: (1) Gonostyli (i.e., styli moved by muscles and used in male copulatory apparatus) are absent in all Metapterygota; immovable non-functional styli are retained in male genitals of Notoptera, some Pandictyoptera and some Saltatoria; in all Eumetabola (to which Zoraptera belong) primary styli are lost [Kluge, 2003]. (2) Two-segmented cerci are present in Embioptera only [see Idioprothoraca (2)]; one-segmented cerci, besides Zoraptera, are present in Odonata, Spectra, Saltatoria, recent Dermatoptera, some Plecoptera and some Pandictyoptera. (3) Thickened hind femora with strengthened tibial depressors of the same fan-like shape as in Embioptera and Zoraptera, are present in Notoptera, Dermatoptera and many other insects, which are adopted for crawling in narrow spaces. In these insects hind femora are larger than others, but shape of muscles is similar in femora of all three pairs of legs: both depressor and levator are fan-form and attachet not only to the base, but also to the dorsal (outer) side of femur; depressor is thicker than levator, and its numerous fan-form dorsal fibers overlap levator [Walker, 1938: Fig. 36]. In Embioptera and Notoptera not only femorotibial depressors, but also tibio-tarsal muscles are thickened and fan-forme; possibly, this is an autapomorphy of Idioprothoraca. (4) Anal fan is not lost: ancestors of Idioprothoraca never had anal fan, whose presence is an autapomorphy of Rhipineoptera (see below). (5) In Embioptera females are always apterous, while in Zoraptera apterous morphs are not connected with sex; apterous morphs or apterous sexes are found in many insects, belonging nearly to all orders of Neoptera. (6) Wings are shed in Zoraptera, but not in Embioptera; Zoraptera have no special basal fracture; besides Zoraptera, wings are shed in various insect taxa (ants among Hymenoptera, some louse flies among Diptera, and others). (7) Embioptera have signs of 4 tarsomeres on hind legs and never have 2segmented tarsi; 2-segmented tarsi of Zoraptera testify about their belonging to Parametabola (see below). (8) Neither gregarious, nor maternal behavior is a common character of Embioptera and Zoraptera. Embioptera (both adults and larvae) are gregarious, because they need to use common nests with silk galleries, that is a unique autapomorphy of Embioptera. Watching various species of Zoraptera (particularly, Zorotypus huxleyi Bolivar y Pieltain \& Coronado, 1963, which is abundant in Peruvian Amazonia), I was unable to see any sings of gregarious behavior: on each dead tree trunk available for their inhabitance, all individuals are evenly dispersed along the trunk, not forming any aggregations (in contrast to all other insect species found on the same trunks). Nothing is known about maternal behavior of Zoraptera; their larvae keep themselves independently from adults.

Yoshizawa [2007] reported one more assumed synapomorphy of Embioptera and Zoraptera: posterior notal wing process is separated from notum and fused with axillary sclerite. Actually, shape of posterior notal wing process in Zoraptera is unusual, but in Embioptera it is the same as in most other insects and not separated from notum [Matsuda, 1970: Fig. 50].

\subsubsection{Notoptera Crampton, 1915}

Typified name in basic format: Grylloblatta/fg; typified names in use: Grylloblattidae, Grylloblattoidea, Grylloblattodea, Grylloblattida, Grylloblattaria and others.

Circumscription of Notoptera. Here the name Notoptera is applied to a small taxon comprising genera Grylloblatta Walker, 1914, Galloisiana Caudell, 1924, Grylloblattina BeiBienko, 1951, Grylloblattella Storozhenko, 1988 and Namkungia Storozhenko \& Park, 2002. Its distribution is limited by Amphipacific Sector of Holarctic and fossils are unknown. Some authors apply the same name "Notoptera" for a wider taxon (Notoptera sensu Arillo \& Engel, 2006), which includes African Mantophasmatoda; in such sense the taxon "Notoptera" is polyphyletic and has no diagnosis (see below).

Systematic position of Notoptera. Originally, the generic name Grylloblatta was given in connection with symplesiomorphies with Saltatoria (long ovipositor) and with Neoblattariae (cursorial legs with five-segmented tarsi) (Walker, 1914). Till now, Notoptera are placed to a plesiomorphon Polyneoptera comprising both Saltatoria and Neoblattariae (see discussion on Idioprothoraca above).

Some authors [e.g., Handlirsch, 1925] regarded Notoptera to be a member of a certain taxon within Saltatoria. Judging by fully developed trochanters on all legs and multisegmented cerci [see Idioprothoraca (2)], Notoptera could not originate from any group within Saltatoria, whose trochanters of hind legs are incomplete, and cerci are onesegmented.

Being attributed to Polyneoptera, Notoptera are often united with various Paleozoic and Mesozoic winged insects with developed anal fan to form a plesiomorphon ancestral to some or all other Polyneoptera [Rasnitsyn, 1976, 1980; Storozhenko, 2002]. Among extinct insects, Jurassic Blattogryllidae and Permian Tillyardembiidae are regarded to be most closely related to Notoptera [Rasnitsyn, 1976; Grimaldi \& Engel, 2005; Arillo \& Engel, 2006]. However, these insects can not belong to Notoptera, because their thorax structure is 
different from that of Idioprothoraca: in Blattogryllus karatavicus Rasnitsyn, 1976 prothorax is not elongated [Rasnitsyn, 1976: Figs 1: I-III; Rasnitsyn, 1980: Pl. VIII: Fig. 26; Rasnitsyn \& Quicke, 2002: Fig. 407; Grimaldi \& Engel, 2005: Fig. 7.53]; in Tillyardembia antennaeplana Zalessky,
1938 prothorax is elongated anteriad of leg bases like in Idioprothoraca; but, judging by its long sternopleurite and short cervical sclerites, is has no pseudopleurites [Grimaldi \& Engel, 2005: Fig. 7.54]. Other known fossil insects have no any characters common with Notoptera.
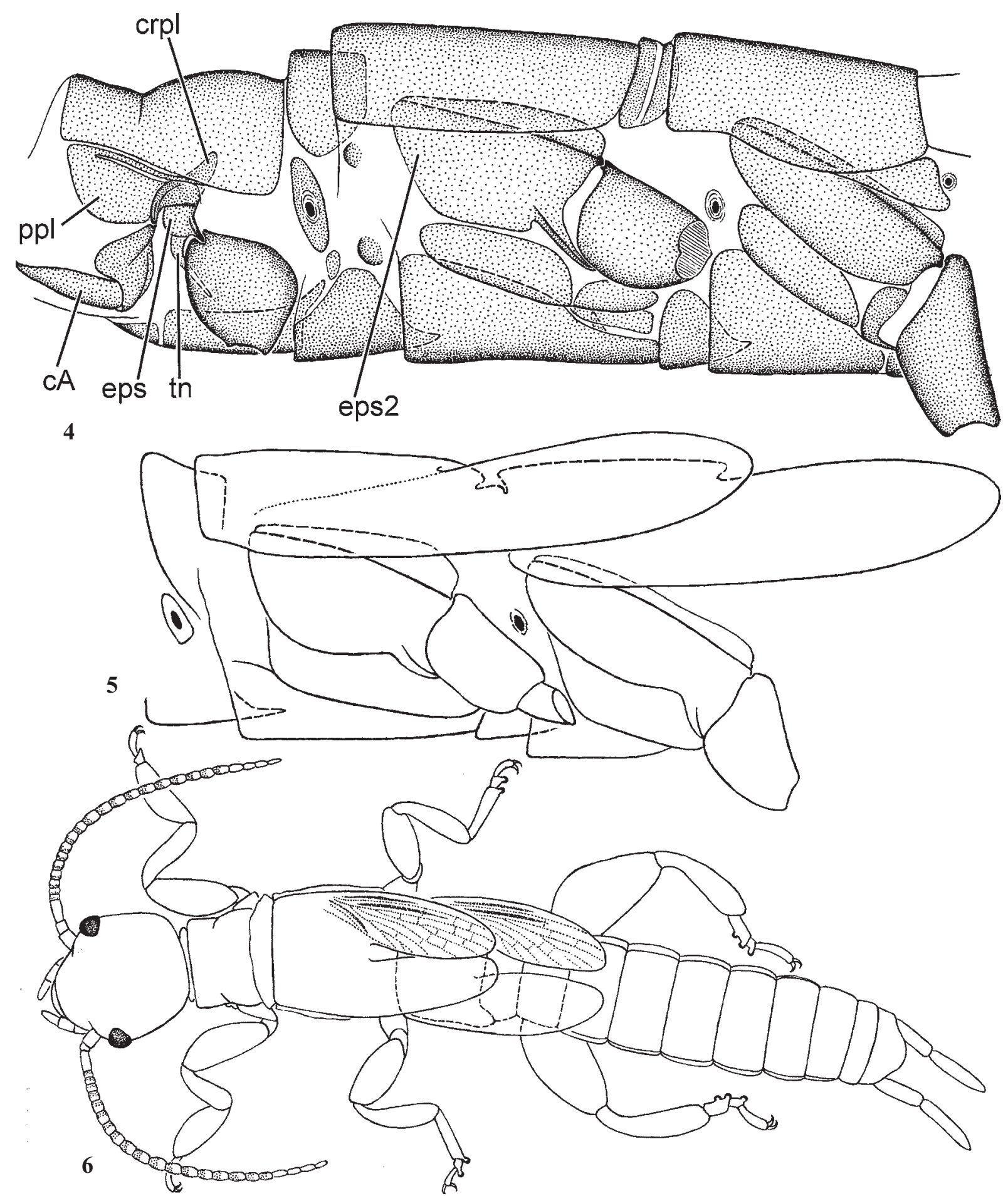

Figs 4-6. Embioptera, Clothoda: 4 - female imago of C. longicauda Ross, 1987; 5-6 - last instar male larva of C. amazonica sp.n.: 4 - thorax, lateral view; 5 - pterothorax, lateral view; 6 - total, dorsal view; cA — anterior part of cervical sclerite; crpl — cryptopleurite; eps - episternum of prothorax; eps2 - episternum of mesothorax; ppl — pseudopleurite; tn — trochantin of prothorax.

Рис. 4-6. Embioptera, Clothoda: 4 - самка имаго C. longicauda Ross, 1987; 5-6 - личинка последнего возраста C. amazonica sp.n.; 4 - грудь, латерально; 5 - птероторакс, латерально; 6 - общий вид, дорсально; сA - передняя часть шейного склерита; crpl криптоплейрит; eps — эпистернум переднегруди; eps 2 - эпистернум среднегруди; ppl一 псевдоплейрит; tn — трохантин переднегруди. 
Recently some authors unite Notoptera and Mantophasmatidae to a taxon XeNONOMia Terry \& Whiting, 2005 (circumscriptional synonym: NeONOTOPTERA Engel in Arillo \& Engel, 2006). For this taxon, no one apomorphic character has been reported, apart of the loss of wings and ocelli. Wingless representatives are found in all orders of Neoptera; loss of wings is often accompanied by loss of ocelli. Holophyly of Xenonomia is said to be based on nucleotid sequences of some genes [Terry \& Whiting, 2005], but no one gene character common for Notoptera and Mantophasmatidae, has been reported. Systematic position of Mantophasmatidae is vague, because they lack wings; probably, they belong to Spectra within Rhipineoptera.

\subsection{RHIPINEOPTERA taxon nov.}

Typified name in basic format: Gryllus/f=Forficula/g. ETYMOLOGY. pıлıs (fan) + Neoptera; due to presence of anal fan on hind wing.

CHARACTERISTICS. Autapomorphy. Hind wing has anal fan consisted of a number of straight diverging anal veins, which is able to fold like a fan and turn over together with $3^{\text {rd }}$ axillary sclerite (see Autapomorphy of Neoptera). In some taxa (Isoptera-Hemiclidoptera, some Neoblattariae) anal fan lost ability to fold, so it turns over in flat condition. In some other taxa (Isoptera-Cryptoclidoptera and some Plecoptera) anal fan is reduced so strongly, that becomes unable neither to fold, nor to turn over. But in all cases fore and hind wings retain the difference in structure of their anal-proximal areas, which indicates that originally hind wing had the anal fan, while fore wing never had it (Figs 9-10). In this respect Rhipineoptera differ from Idioprothoraca, whose fore and hind wings can have the same structure of their anal-proximal areas (Fig. 7).

COMPOSITION. Rhipineoptera include PleCOPTERA Burmeister, 1839, Pandictyoptera Crampton, 1917, Saltatoria Latreille, 1817, Spectra Latreille, 1802 and Dermatoptera Burmeister, 1838 [about usage of these circumscriptional names - see Kluge, 2010a].

\subsection{Eumetabola Hennig, 1953}

Typified name in basic format: Scarabaeus/fg (sine Embia, Forficula; incl. Cicada).

\section{Autapomorphy of Eumetabola:}

(1) Third valves of ovipositor, if developed, form a sheath of ovipositor of the following structure: the sheath of ovipositor is crossed by a membranous area, which separates two immovably connected portions - proximal and distal ones; the proximal portion is immovably attached to IX abdomere by its long dorsal side, so only its ventral side is free; the distal portion has both distal and ventral sides free and forms one line with the proximal portion. Origin of the distal portion is vague: it either represents fused styli (whose muscles are lost, as in all other Metapterygota), or represents a separated distal part of styliger (in this case true styli are lost). Among Parametabola, such ovipositor occurs in Hemelytrata only, among Metabola - in Hymenoptera only. In all other taxa of Eumetabola ovipositor either lacks third valves, or is highly modified, or vestigial, or completely lost.

\section{Non-unique characters of Eumetabola:}

(2) Larvae lost ocelli. The same in many other taxa.

(3) Cryptosterny is usually more or less expressed (sometimes poorly expressed or absent).

(4) Styli are lost at least in males [about females see (1)]. The same in many other taxa. Parameres and other movable paired appendages, which occur in genital apparates of many Eumetabola, are not homologous to styli [Kluge, 2003].
(5) Number of Malpighian tubes is usually small and constant -4 pairs or less (only imagoes of Hymenoptera have highly increased number of Malpighian tubes). In most other Pterygota number of Malpighian tubes is large and indeterminate.

Classification. The taxon Eumetabola is divided into two taxa - Parametabola and Metabola.

\subsubsection{Parametabola Crampton, 1938}

Non-monosemantic circumscriptional synonymy:

$=$ PANHOMOPTERA Crampton, 1919, s.1.;

$=$ PARANEOPTERA Martynov, 1923, s.l.

Typified name in basic format: Cimex/f=Cicada/g (incl. Zorotypus).

Autapomorphies of Parametabola.

(1) Wing apparatus is anteromotoric: fore wing is leading, while hind wing is coupled with it and moves passively. Non-unique apomorphy: the same in recent Ephemeroptera and certain Metabola (Hymenoptera, some Lepidoptera and some Trichoptera). Unlike them, in Rhipineoptera and Idioprothoraca wing coupling never occurs.

(2) Fore wing has areola postica - a cell of characteristic shape. Well-expressed areola postica is present in Zoraptera, many Copeognatha, Saltipedes and some other taxa; sometimes it is poorly expressed or lost.

(3) Apical tibial spoors are lost. The same in Embioptera, Spectra, Dermatoptera and some other taxa.

(4) Tarsus initially has 2 segments in larva and 3 segments in imago; in course of the last moult, distal segment of the 2segmented larval tarsus is transformed to $2^{\text {nd }}$ and $3^{\text {rd }}$ segments of the 3-segmented imaginal tarsus. Secondarily, number of tarsal segments can be decreased; often larval 2-segmented tarsal structure is retained in imago. Among other taxa, 3segmented tarsi are rather usual (in recent Odonata, Embioptera, Plecoptera, some Saltatoria, some Spectra, recent Dermatoptera and some others), but 2-segmented tarsi are very rare.

(5) All abdominal ganglia are fused together. The same in some other taxa.

Classification. The taxon Parametabola is divided into two taxa - Zoraptera Silvestri, 1913 and AcERCARIa Börner, 1904.

Systematic position of Zoraptera. Zoraptera combine apomorphies common with Acercaria (see autapomorphies of Parametabola) and plesiomorphies common with Polyneoptera (i.e., Rhipineoptera + Idioprothoraca) - presence of cerci and non-retractable maxillary laciniae. According to the phylogenetic approach, symplesiomorphies are ignored and synapomorphies are used as an argument to unite Zoraptera with Acercaria into the taxon Parametabola (= Paraneoptera s.1.) [e.g., Martynov, 1938; Crampton, 1938; Hennig, 1969, 1981].

Some authors use a non-phylogenetic approach: basing on symplesiomorphies only, they unite Zoraptera with Polyneoptera to a taxon UROTA Chen, 1962 [circumscriptional synonym: Polyneopterata Boudreaux, 1979]. According to their logic, "Zoraptera can be excluded from the Paraneoptera based on their primitive retention of cerci, the presence of a first abdominal sternum, and the broad orthopteroid lacinia" [Grimaldy \& Engel, 2005: 192]. It was suggested to unite Zoraptera and Pandictyoptera to a taxon CURSORIDA Boudreaux, 1979 and to unite Cursorida, Dermatoptera and Notoptera to a taxon BLATTONEOPTERA Kukalova-Pack \& Brauckmann, 1992 [KukalovaPeck \& Peck, 1993]; no one really existent character of Cursorida and Blattoneoptera have been reported.

Terry \& Whiting [2005] united Zoraptera and Dermatoptera to a taxon HAPLOCERCATA Terry \& Whiting, 2005. Holophyly of this taxon was argued by non-segmented cerci and 
by nucleotid sequences of some genes; however, no one gene character had been reported. Non-segmented cerci are found in many taxa, while in Dermatoptera cerci are initially multisegmented.

Rafael \& Engel [2006] united Zoraptera and Embioptera to a taxon Mystroptera (see above, discussion on Embioptera).

\subsection{2. Метавоla Burmeister, 1832}

Circumscriptional synonymy:

= OLIGONEOPTERA Martynov, 1923;

= EUNEOPTERA Martynov, 1924.

Typified name in basic format: Scarabaeus/fg (sine Cicada).

Autapomorphies of Metabola. This taxon is known as

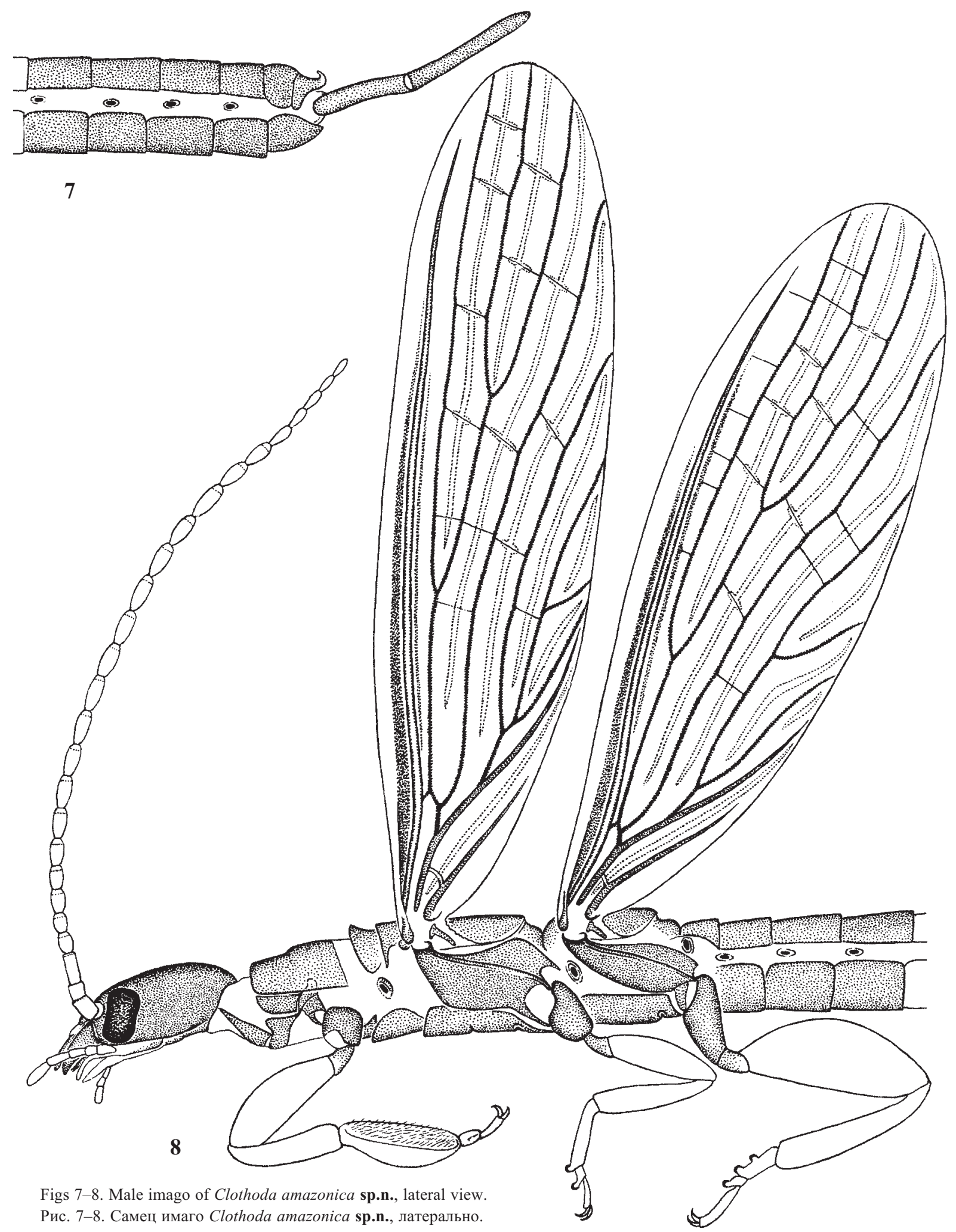


insects with complete metamorphosis. In spite of the fact, that holophyly of this taxon is generally accepted, its most important autapomorphies, which are connected with metamorphosis, remained to be unknown till the last time. For the first time, they were described in my paper [Kluge, 2005].

Formerly, it was regarded that metamorphosis of male coccids (which belong to Parametabola) has some similarity with complete metamorphosis. Recently, it have been discovered that both male and female coccids have a special kind of metamorphosis, which is an autapomorphy of Gallinsecta and has nothing in common with the complete metamorphosis of Metabola [Kluge, 2010b].

\section{Description of a new species of Embioptera}

\section{Clothoda amazonica sp.n.}

Figs 5-8, 11-21

MATERIAL. Peru, between Puente Itaya $(57 \mathrm{~km}$ by road from Iquitos) and San Joaquin on Rio Amazon; native forest, a large nest on tree, 11.II.2006, coll. N. Kluge - $O^{7}$ imago. Paratypes: the same nest, $3 \sigma^{7}$ imagoes, $1 \sigma^{7}$ imago with nymphal exuviae, $24 \sigma^{7}$ nymphs, 55 nymphs. Other nests at the same place -5 nymphs

DESCRIPTION. Imago, male. CUTICULAR COLORATION: Sclerites light brownish, membranes colorless; cuticular coloration poorly visible on background of darker hypodermal coloration. Vertex between eyes with large transverse blank (coincides with ocher hypodermal spot). Cuticle of submentum darker than on other body, especially near front and lateral margins. Gula lighter than submentum, with paired setal tufts (characteristic for Clothoda) contrastingly dark brown. Biting edge of mandibles black. Other sclerites with diffusive lighter and darker areas.

HyPODERMAL COLORATION: Dorsal side of head brown with large ocher maculae: transverse ocher macula between eyes (coincides with cuticular blank; 5 longitudinal ocher maculae behind; 3 maculae behind them (Fig. 11). Clypeo-labral membrane whitish; labrum brown. Lateral and ventral sides of head lighter brown-ocher; submentum entirely dark brown; lateral parts of mentum, segments of labial palps and maxillary palps brown; intersegmental membranes and apical papillae of palps whitish. Scapus, pedicellus and most flagellomeres brown; joinings of scapus, pedicellus and a few most proximal flagellomeres colorless; $3-5$ apical flagellomeres whitish.

Pronotum with composite ornament of brown and ocher maculae (Fig. 11). Ventral side of thorax with brown, ocher and whitish maculae (Fig. 12). Hypodermal coloration of legs variable: just after molt it has contrasting ocher and brown areas, as in larva (see below); in mature imago legs become at most brown, fore tarsus retains contrasting longitudinal ocher line on sole side of 1st segment and light sole side of 2nd segment.

Abdominal terga either entirely brown, or with ocher maculae. Pleural area either entirely ocher, or ocher with brown maculae. Abdominal sterna have wide median area ocher, narrower lateral areas brown. Cerci just after molt ocher with brown maculae on 1st segment, in mature imago become uniformly brown.

COLORATION OF WINGS (cuticular plus hypodermal). Membrane dark brown, with narrow hyaline intervals (Figs 7, 11); field behind Sc colored by darker brown up to wing middle. Cuticle of RA looks as double dark brown line, bordered by hyaline fields; hypoderm of these fields form two narrow longitudinal dark brown or purple hypodermal stripes - in front and behind RA, thus RA looks as 4 parallel longitudinal lines, which are expressed at least in middle part of wing. $\mathrm{Cu}_{2}$ has dark brown cuticular coloration. Other longitudinal veins and crossveins brown, a little darker than background; some crossveins partly hyaline or bordered by hyaline.

SHAPE AND SETATION. As in Clothoda longicauda (genitals Fig. 15)

Imago, female. Unknown.

Larva (male and female). CUTICULAR COLORATION: Cuticle very thin, soft, colorless; only mandibles sclerotized and pigmented. After molt shed cuticle is crumpled.

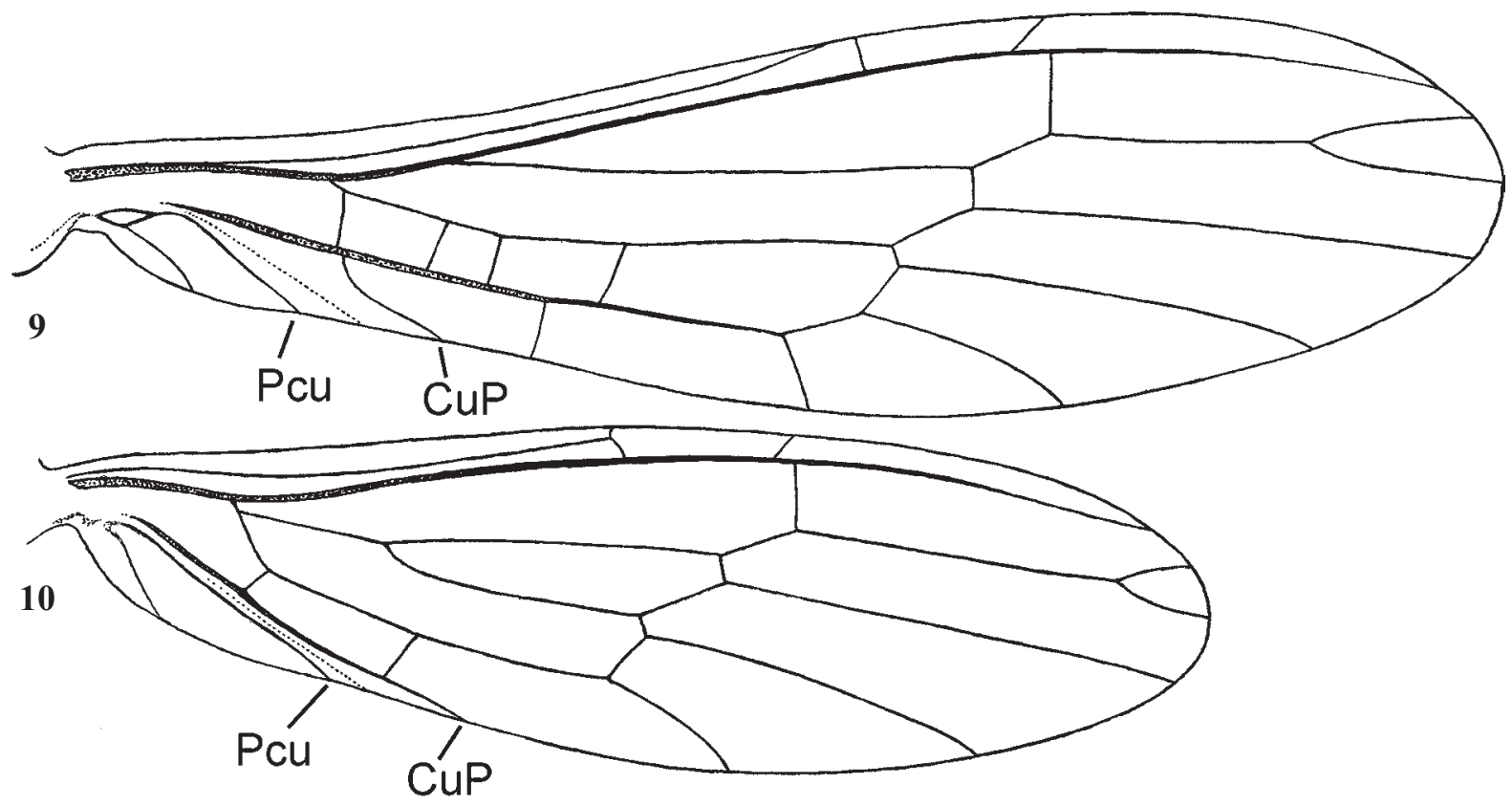

Figs 9-10. Rhipineoptera: fore (9) and hind (10) wings of female Chloroperla apicalis Newman, 1836 as example of Plecoptera with reduced anal fan.

Рис. 9-10. Rhipineoptera: переднее (9) и заднее (10) крылья самки Chloroperla apicalis Newman, 1836, как пример Plecoptera с редуцированным анальным веером. 
HyPODERMAL COLORATION. Dorsal side of head brown with large ocher maculae in posterior part (as in imago), but without transverse ocher macula between eyes; clypeus ocher with brown maculae (unlike entirely brown in imago) (Fig. 16). Ventral side of head light with brown. Most segments of flagellum are brown in middle, with ocher in distal part, dark brown at apex; 3-5 apical segments colorless (Fig. 16).

Legs with contrasting ocher and brown areas (Figs 1718): coxa ocher with brown maculae; femur and tibia brown

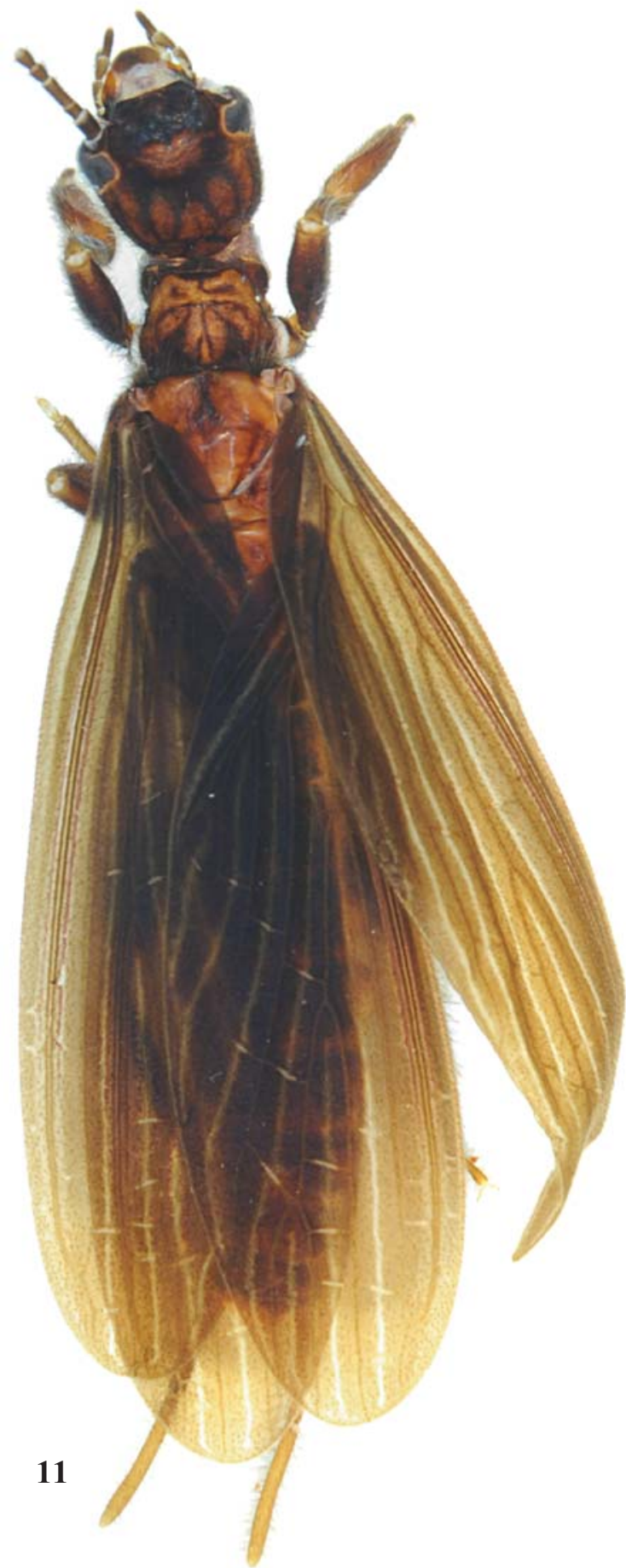

with knee area ocher; 1 st segment of fore tarsus brown with lighter sides, its sole side brown with longitudinal ocher line; other tarsi at most ocher.

Each protopteron ocher, with contrasting dark brown base and 3 narrow longitudinal lines: along costal margin, between $\mathrm{Sc}$ and $\mathrm{RA}$ and between $\mathrm{RA}$ and $\mathrm{RS} ; \mathrm{Cu}_{2}$ and neighboring areas tinged with grayish; other veins lighter than background.

Abdominal terga either entirely brown, or with ocher maculae. Pleural area either entirely ocher, or ocher with

Figs 11-12. Clothoda amazonica sp.n., male imago, holotype: 11 - dorsal view; 12 - ventral view. Рис. 11-12. Clothoda amazonica sp.n., самец имаго, голотип: 11 - сверху; 12 - снизу. 
brown maculae (Fig. 19). Abdominal sterna have wide median area ocher, narrower lateral areas brown. Cercus has first segment ocher with brown maculae, apex brown; second segment entirely ocher (Fig. 19).

Nest. Made on tree, fully exposed, brown, consists of silk with powder of masticated material. A nest represents
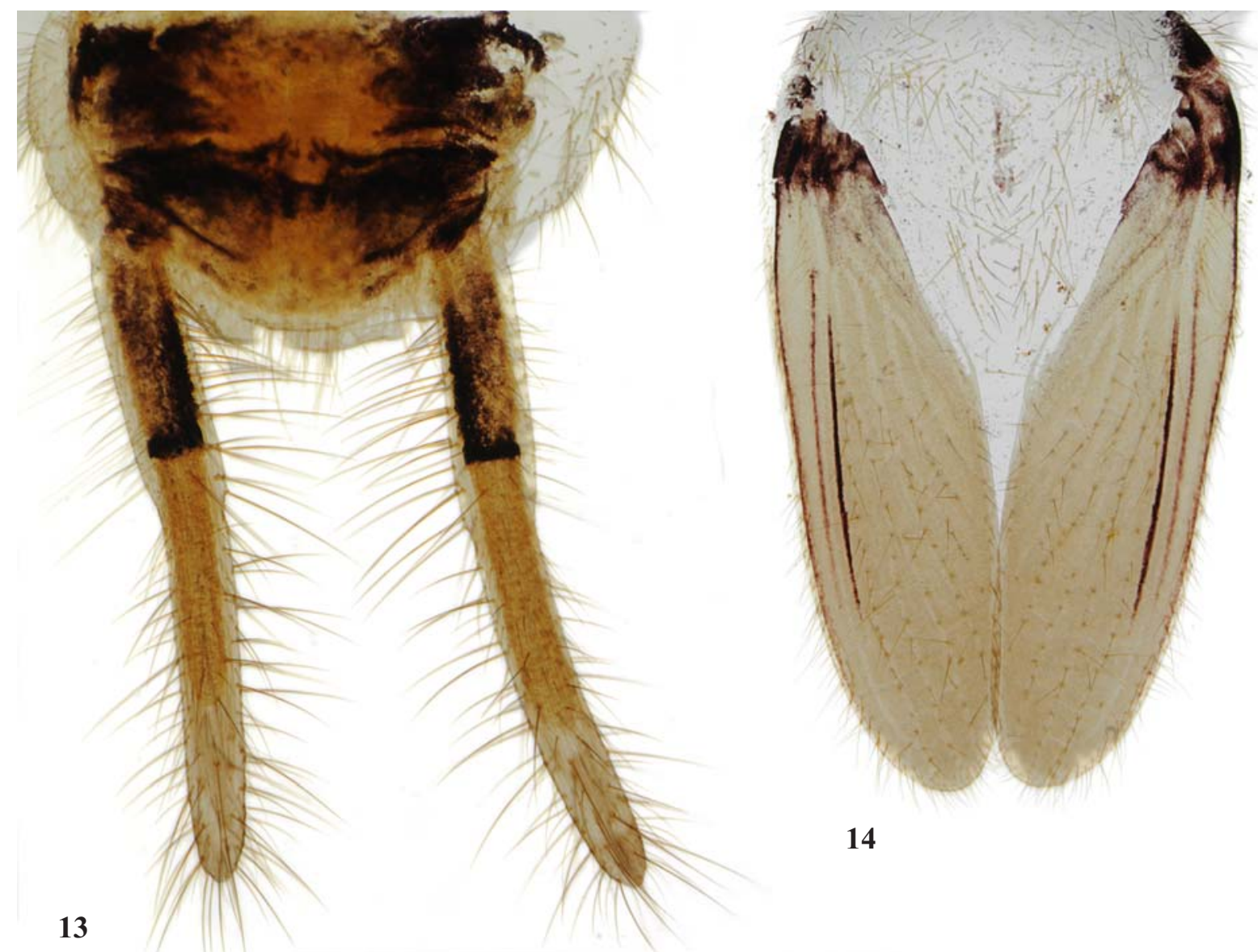

14

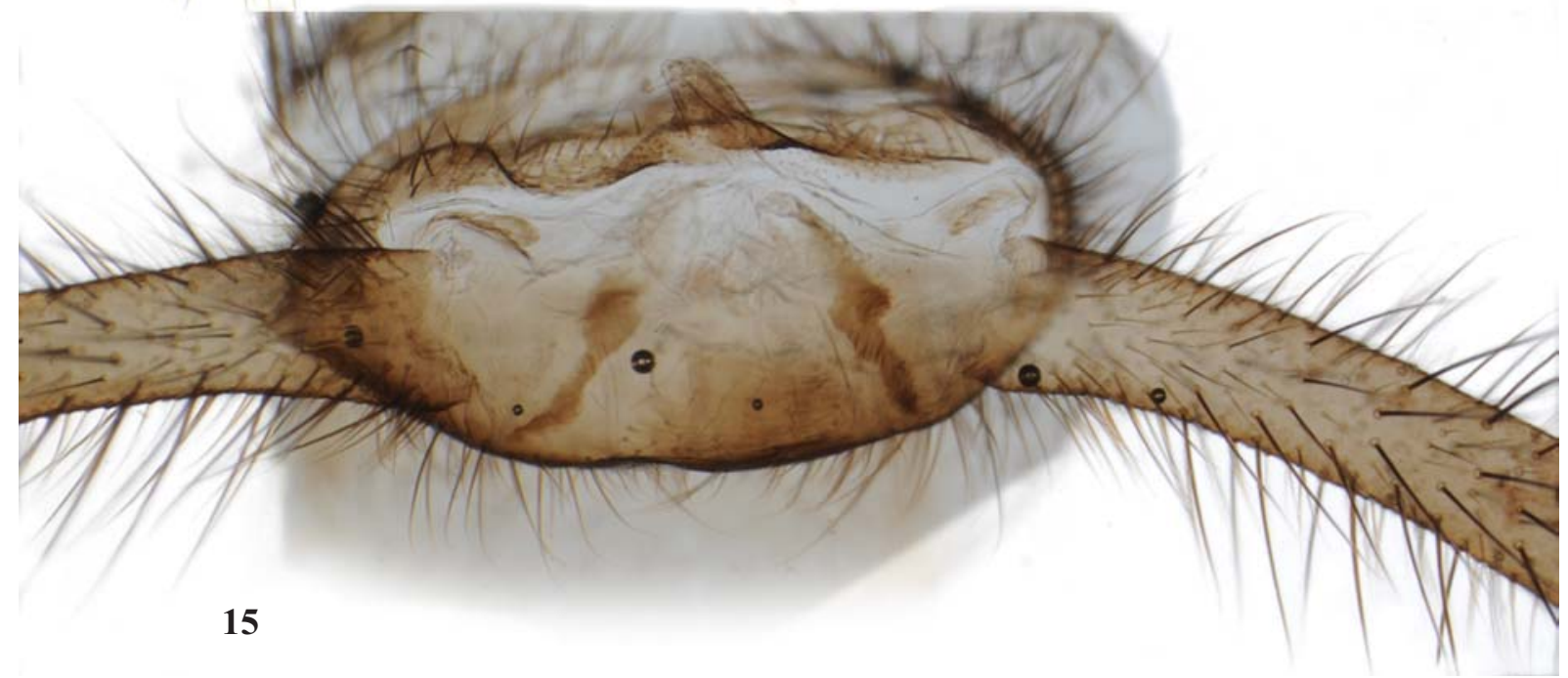

Figs 13-15. Clothoda amazonica sp.n.: 13 - cerci of last instar male larva; 14 - fore protoptera of last instar male larva; 15 — genitals of male imago treated by alkali, caudal view (holotype).

Рис. 13-15. Clothoda amazonica sp.n.: 13 - церки личинки последнего возраста; 14 - передние протоптероны личинки самца последнего возраста; 15 - гениталии самца имаго, обработанные щелочью, вид сзади (голотип). 
piece of textile, and no remainders of silk were left on the tree (Fig. 21).

DIMENSIONS. Body length $13 \mathrm{~mm}$ (without antennae and cerci); fore wing length $10 \mathrm{~mm}$.
COMPARISON. New species differs from Clothoda nobilis (Gerstaecker, 1888) by coloration of wings, which is the same as in C. longicauda Ross, 1987.

Imago of the new species differ from Clothoda longicau$d a$ by lighter hypodermal coloration of body, with large ocher

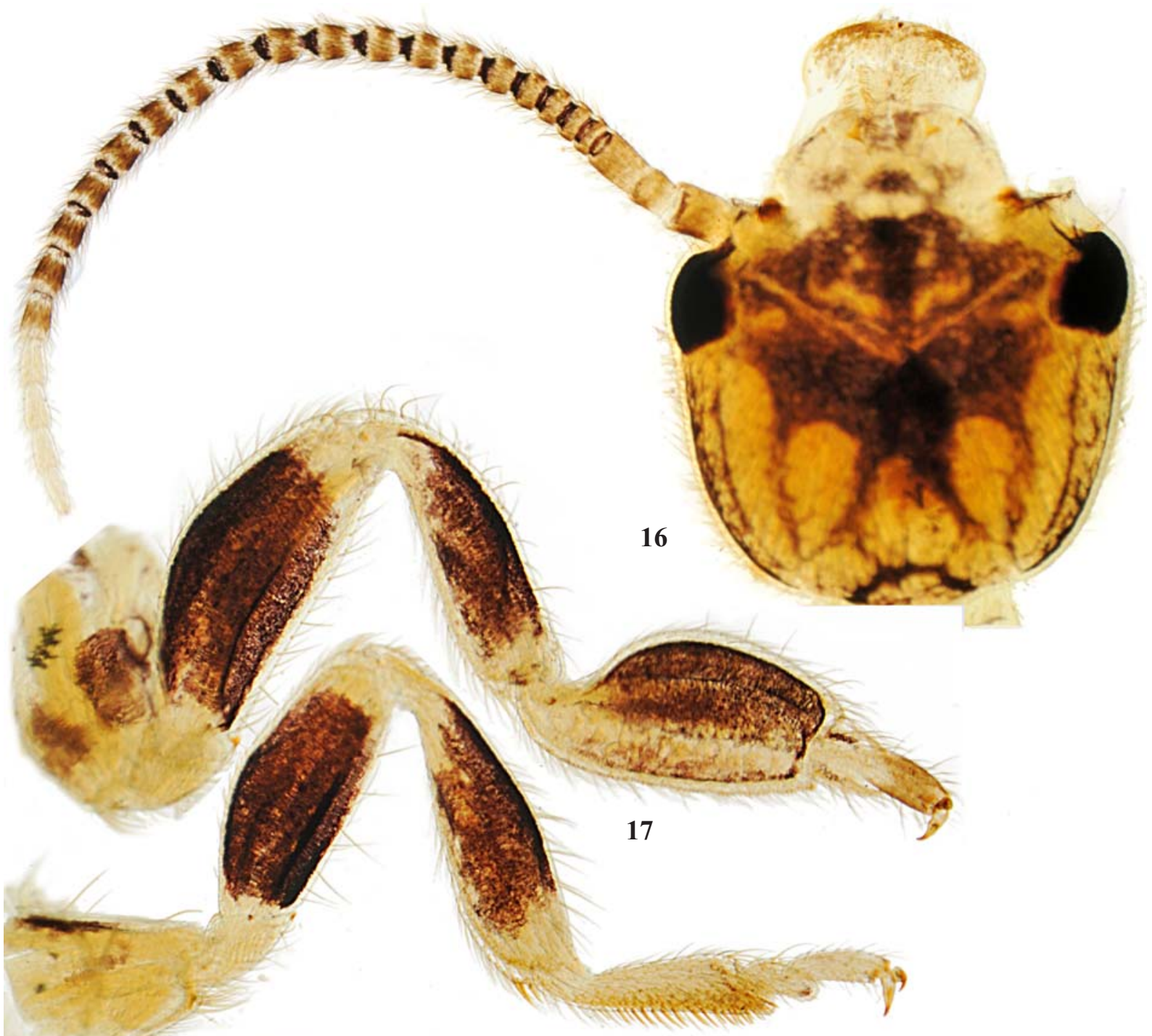

18

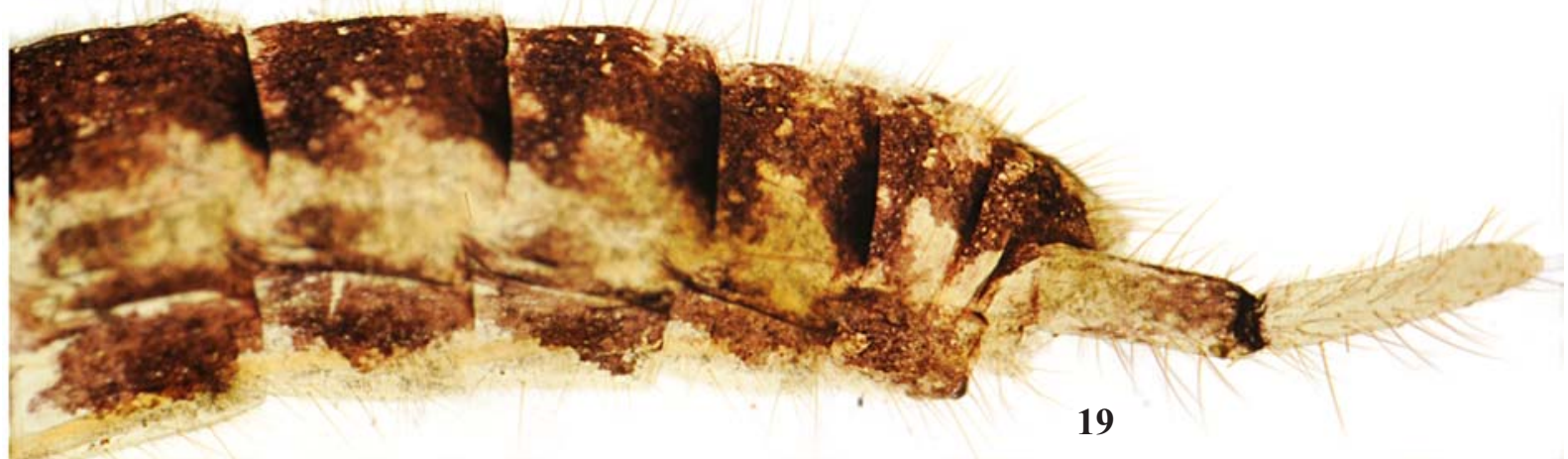

Figs 16-19. Clothoda amazonica sp.n., last instar male larva: 16 - head; 17 — fore leg; 18 - middle leg; 19 — hind part of abdomen and left cercus, lateral view.

Рис. 16-19. Clothoda amazonica sp.n., личика последнего возраста: 16 — голова; 17 - передняя нога; 18 — средняя нога; 19 задняя часть брюшка и левый церк, латерально. 
maculae on posterior half of head, pronotum, ventral side of thorax, pale abdominal pleura and light ocher middle part of sterna. Larva and young imago differs by the same features, plus contrasting light bases, knees and apices of legs and light $2^{\text {nd }}$ segments of cerci. Silk nest differs by brown color. Unlike it, $C$. longicauda has dark brown hypodermal coloration both in imago and larvae; its nests are always white.
Clothoda longicauda Ross, 1987 Fig. 4

MATERIAL EXAMINED. Peru, near Tingo Maria, Puente Perez, plantations of orange and cacao near native forest, in several nests on trees, 22.I.2006, coll. N. Kluge $-4 \sigma^{7}$ imagoes, 7 ? imagoes, 4 nymphs.

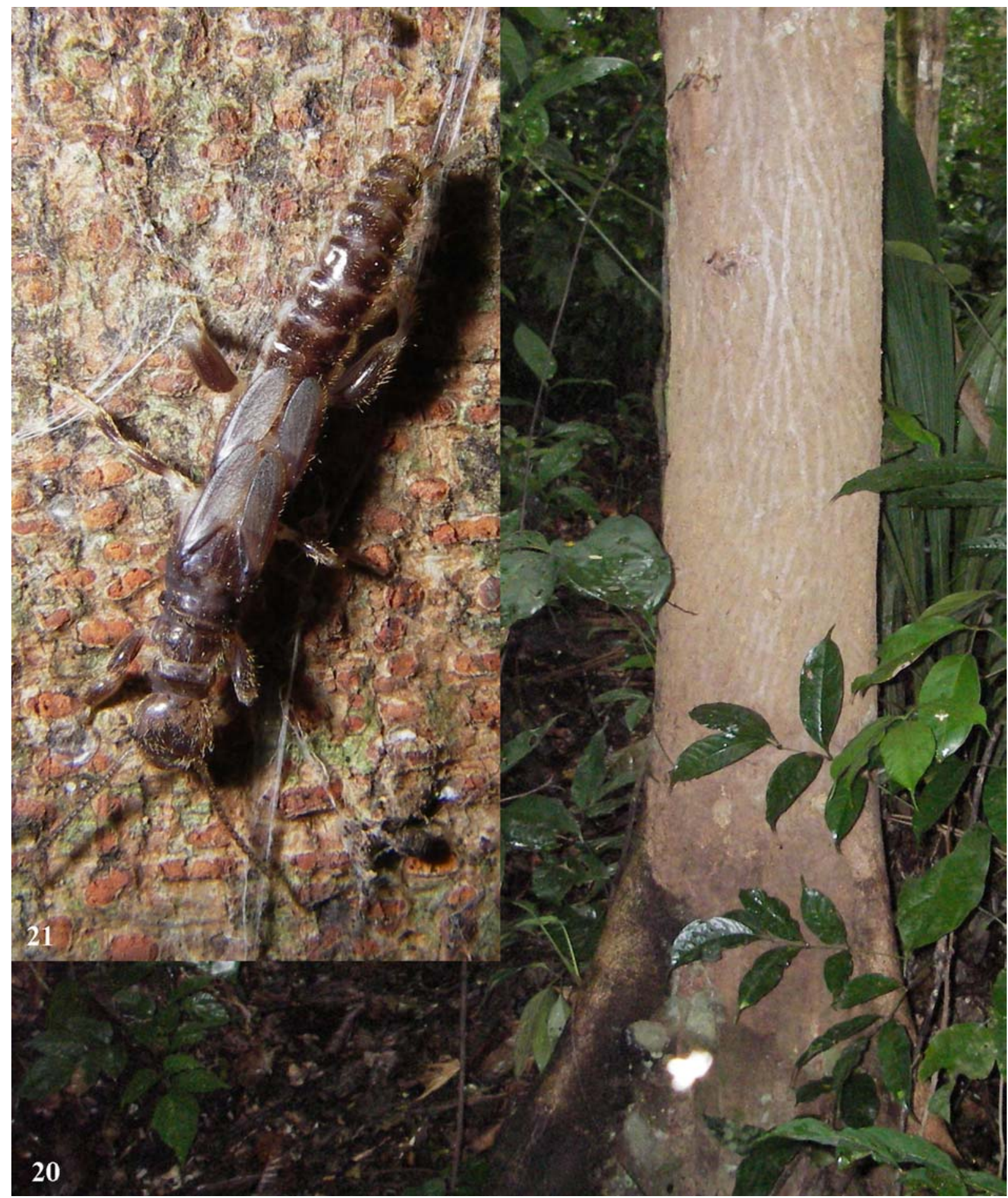

Figs 20-21. Clothoda amazonica sp.n.: 20 — nest on a tree; 21 — last instar male larva on the same tree, after removing the nest.

Рис. 20-21. Clothoda amazonica sp.n.: 20 - гнездо на дереве; 21 - личинка самца последнего возраста на том же дереве после удаления гнезда. 
ACKNOWLEDGEMENTS. The author thanks S. Storozhenko for material on Grylloblattina djakonovi. This investigation was supported by the Russian Federal Program for Support Leading Scientific Schools, grant No.332.2010.4.

\section{References}

Arillo A., Engel M.S. 2006. Rock crawlers in Baltic amber (Notoptera: Mantophasmatodea) // American Museum Novitates. No.3539. P.1-10.

Börner C. 1904. Zur Systematic der Hexapoden // Zoologischer Anzeiger. Bd.27. S.511-533.

Boudreaux H.B. 1979. Arthropod phylogeny with special reference to insects. New York, Chichester, Brisbane, Toronto: John Willey \& sons. 320 p.

Brullé M. 1832. 2 section - Des animaux articules // Expedition scientifique de Moree. Section des sciences physiques. Tome III. 1-re Partie. Zoologie. Paris. 400 p.

Burmeister H. 1832. Handbuch der Entomologie. Bd.1. Allgemeine Entomologie. Berlin: G. Reimer. $696 \mathrm{~S}$.

Burmeister H. 1838. Handbuch der Entomologie. Bd.2. Besondere Entomologie. Abt.2. Kaukerfe. Gymnognatha. Hf.1. Vulgo Orthoptera. Berlin: G. Reimer. S.397-756.

Burmeister H. 1839. Handbuch der Entomologie. Bd.2. Besondere Entomologie. Abt.2. Kaukerfe. Gymnognatha. Hf.2. Vulgo Neuroptera. Berlin: G. Reimer. S.757-1050.

Chen S.H. 1962. [Types of insect metamorphosis and a new system of insect classification] // Acta Entomologica Sinica. Vol.11. No.1. P.1-15 [in Chinese].

Crampton G.C. 1915. The thoracic sclerites and the systematic position of Grylloblatta campodieformis Walker, a remarkable annectant, "Orthopteroid" insect// Entomological News. Vol.26. No.10. P.337-350

Crampton G.C. 1916. The lines of descent of the lower pterygotan insects, with notes on the relationships of the other forms // Entomological News. Vol.27. No.6. P.244-258; No.7. P.297307.

Crampton G.C. 1917. A phylogenetic study of the lateral head, neck and prothoracic regions in some Apterygota and lower Pterygota // Entomological News. Vol.28. No.9. P.398-412.

Crampton G.C. 1919. Notes on phylogeny of the Orthoptera // Entomological News. Vol.30. No.2. P.42-48; No.3. P.64-72.

Crampton G.C. 1924. The phylogeny and classification of the insects // Journal of Entomology and Zoology. Vol.16. P.33-47.

Crampton G.C. 1938. The interrelationships and lines of descent of living insects // Psyche. Vol.45. No.4. P.165-181.

Enderlein G. 1909. Die Klassifikation der Embiiden, nebst morphologischen und physiologischen Bemerkungen, besonders über das Spinnen derselben // Zoologischer Anzeiger. Bd.35. H.6. S.166-191.

Engel M.S., Grimaldi D.A. 2000. A winged Zorotypus in Miocene amber from the Dominican Republic (Zoraptera: Zorotypidae), with discussion on relationships of and within the order // Acta Geologica Hispanica. Vol.35. No.1. P.149-164.

Grimaldi D., Engel M.S. 2005. Evolution of the insects. Cambridge University Press. $755 \mathrm{p}$

Handlirsch A. 1925. Geschichte, Literatur, Technik, Palaontologie, Phylogenie, Systematik // Schroder Ch. (Hrsg.). Handbuch de Entomologie. Bd.3. Jena. S.1-1201.

Hennig W. 1953. Kritishe Bemerkungen zum phylogenetischen System der Insecten // Beiträge zur Entomologie. Sonderheft 3. S.1-85.

Hennig W. 1969. Die Stammesgeschichte der Insecten // Senkenberg-Bucherei. Frankfurt am Main: Krammer. Bd.49. $436 \mathrm{~S}$.

Hennig W. 1981. Insect phylogeny. Chichester, N.Y., Brisbane, Toronto: John Wiley \& Sons. 514 p.

Kluge N.J. 2003. [About evolution and homology of genital appendages of insects] // Trudy Russkogo Entomologicheskogo Obshestva / Proceedings of the Russian Entomological Society. Vol.74. P.3-16 [in Russian].
Kluge N.J. 2005. Larval/pupal leg transformation and a new diagnosis for the taxon Metabola Burmeister, $1832=$ Oligoneoptera Martynov, 1923//Russian Entomological Journal. Vol.13 (2004). No.4. P.189-229.

Kluge N.J. 2010a. Circumscriptional names of higher taxa in Hexapoda // Bionomina. Vol.1. P.15-55.

Kluge N.J. 2010b. Paradoxical molting process in Orthezia urticae and other coccids (Arthroidignatha, Gallinsecta) // Zoosystematica Rossica. Vol.19. No.2. P.246-271.

Kristensen N.P. 1995. Forty years' insect phylogenetic systematics // Zoologische Beitrage (N.F.). Vol.36. No.1. P.83-124.

Kukalova-Peck J. 1973. A phylogenetic tree of the animal kingdom (including orders and higher categories) // National Museum of Canada, Publications in Zoology. No.8. P.1-78, tabl.1-30.

Kukalova-Peck J., Brauckmann C. 1992. Most Paleozoic Protorthopterara are ancestral hemipteroids: mojor wing braces as clues to a new phylogeny of Neoptera (Insecta) // Canadian Journal of Zoology. Vol.70. No.12. P.2452-2473.

Kukalova-Peck J., Peck S.B. 1993. Zoraptera wing structutre: evidence for new genera and relationship with the blattoid orders (Insecta: Blattoneoptera) // Systematic Entomology. Vol.18. No.4. P. 333-350.

Lameere A. 1900. Manuel de la faune de Belge. Tome II. Insectes inferieurs. Bruxelles: H. Lamertin. 858 p.

Lameere A. 1936. Precis de zoologie. Tome VI. Fasc.1. Publications de l'Institut Zoologique Torley-Rousseau. Universite Libre de Bruxelles.

Latreille P.A. 1802. Histoire naturelle, générale et particuliere des Crustacés et des Insectes. T.3. Famille naturelle des genres. Paris: l'Imprimerie de F. Dufart. 382 p, pl.2-15.

Latreille P.A. 1817. Les crustacés, les arachnides et les insectes. In: Cuvier G. Le règne animal distribué d'après son organisation, pour servir de base à l'histoire naturelle des animaux et d'introduction à l'anatomie comparée. Aves figures, dessinées d'après nature. Paris: Deterville. T.3. 653 p.

Martynov A.V. 1923. [About two types of insect wings and their significance for general classification of insects] // [Proceedings of the 1st Russian Congress of Zoologists, Anatomists and Histologists in Petrograd 15-21.XII.1922]. P.88-89 [in Russian].

Martynov A.V. 1924. [On the two kinds of insect wings and their evolution.] // [Russian Zoological Journal]. Vol.4. No.1, 2. P.155-185[in Russian].

Martynov A.V. 1938. [Ocherki geologicheskoy istorii i filogenii otryadov nasekonyh (Pterygota). Chast' I. Palaeoptera i NeopteraPolyneoptera. (Etudes sur l'histoire géologique et de phylogénie des ordres des Insectes (Pterygota) I. Palaeoptera et NeopteraPolyneoptera)] // [Trudy Paleontologicheskogo Instituta Akademii Nauk SSSR (Travaux Inst. Paleont., Acad. Sci. USSR)]. Vol.7. No.4. P.1-449 [in Russian].

Martynova O.M. 1958. [New insects from Pernian and Mesozoic deposits of the USSR] // [Materialy k "Osnovam Paleontologii"] No.2. P.69-94 [in Russian].

Matsuda R. 1970. Morphology and evolution of the insect thorax // Memoirs of the Entomological society of Canada. No.76. P.1431.

Nagashima T. 1991. Postembryonic development and homology of external genitalia in Galloisiana nipponensis (Caudell et King) (Notoptera: Grylloblattidae) // International Journal of Morphology \& Embryology. Vol.20. No.3. P.157-168.

Navás L. 1918. Embiopteros (Ins.) de la America Meridional // Broteria (serie Zoologica). Vol.16. P.85-110.

Rafael J.A., Engel M.S. 2006. A new species of Zorotypus from Central Amazonia, Brazil (Zoraptera: Zorotypidae) // American Museum Novitates. No.3528. P.1-11.

Rasnitsyn A.P. 1976. [Grilloblattidy - sovremennye predstaviteli otryada protoblattod (Insecta, Protoblattodea)] // Dorklady Akademii Nauk SSSR. Vol.228. No.2. P.502-504 (in Russian).

Rasnitsyn A.P. (ed.). 1980. [Istoricheskoe razvitie klassa nasekomyh] // Trudy Paleontologicheskogo Instituta. Vol.175. Moscow: Nauka Publ. P.1-269 [in Russian].

Rasnitsyn A.P., Krasilov V.A. 2000. [The first documented occurrence of phyllophagy in pre-Cretaceous insects: leaf tissues in 
the gut of the Upper Jurassic insects from southern Kazakhstan] // Paleontologicheskiy Zhurnal. No.3. P.71-81 [in Russian, with English summary].

Rasnitsyn A.P., Quicke D.L.J. (eds.). 2002. History of insects. Dordrecht, Boston, London: Kluwer Acad. Publ. 517 p.

Rohdendorf B.B. (ed.). 1962. [Osnovy paleontologii (Basics of paleontology)]. AN. SSSR Publ. Vol. 9. 560 p. [in Russian]

Ross E.S. 1987. Studies in the insect order Embiidina: a revision of the family Clothodidae // Proceedings of the California Academy of Sciences. Vol.45. No.2. P.9-34.

Ross E.S. World list of extant and fossil Embiidina (= Embioptera) Web publication 1999, updated 2009. http://researcharchive. calacademy.org/research/entomology/Entomology_Resources/ embiilist/index.htm\&CFID $=6622202 \&$ CFTOKEN $=72022051$

Shipley A.E. 1904. The orders of insects // Zoologischer Anzeiger. Bd.27. H.7/8. P.259-262.

Storozhenko S.Yu. 2002. Order Grylloblattida // Rasnitsyn A.P., Quicke D.L.J. (eds.). History of insects. Dordrecht, Boston, London: Kluwer Acad. Publ. P.278-283.

Silvestri F. 1913. Descrizione di un nuovo ordine di insetti // Bollettino del Laboratorio di Zoologia Generale e Agraria del Regia Scuola Superiore di Agricoltura di Portici. T.7. P.193-209.

Terry M.D., Whiting M.F. 2005. Mantophasmatodea and phylogeny of lower neopterous insects // Cladistics. Vol.21. P.240-257.

Tillyard R.J. 1937. Kansas Permian Insects. Part 18. The order Embiaria// American Journal of Science. Ser.5. Vol.23. No.196. P.241-251.

Uchifune T., Machida R. 2005. Embryonic development of Galloisiana yuasai Asahina, with special reference to external morphology (Insecta: Grylloblattodea) // Journal of Morphology. Vol.266. P.182-207.

Verhoeff K.W. 1904. Zur fergleichende Morphologie und Systematik der Embiiden // Nova Acta Leopoldino-Carolinae. Deutsche Akademie der Naturforscher. Halle. Bd.82. H.2. S.141214.

Walker E.M. 1914. A new species of Orthoptera, forming a new genus and family // Canadian Entomologist. Vol.46. P.93-99.

Walker E.M. 1838. On the anatomy of Grylloblatta campodeiformis Walker. 3. Exoskeleton and musculature of the neck and thorax // Annals of the Entomological Society of America. Vol.31. P.588-640.

Yoshizawa K. 2007. The Zoraptera problem: evidence for Zoraptera + Embiodea from the wing base // Systematic Entomology. Vol.32. No.2. P.197-204.

Zalessky G. 1938. Nouveaux insectes permiens de l'ordre Embioidea // Annales de la Societe Geologique du Nord. Vol.63. P.62-81. 